\title{
Bone Resorption Inhibitor Alendronate Normalizes the Reduced Bone Thickness of TRPV5 ${ }^{-1-}$ Mice
}

Tom Nijenhuis, ${ }^{1}$ Bram CJ van der Eerden, ${ }^{2}$ Joost GJ Hoenderop, ${ }^{1}$ Harrie Weinans, ${ }^{3}$ Johannes PTM van Leeuwen, ${ }^{2}$ and René JM Bindels ${ }^{1}$

ABSTRACT: TRPV5 is a $\mathrm{Ca}^{2+}$-selective channel involved in transcellular $\mathrm{Ca}^{2+}$ absorption expressed in kidney and in the ruffled border of osteoclasts. Studies in hypercalciuric TRPV5 knockout (TRPV5 ${ }^{-1-}$ ) mice, which display significantly increased vitamin D levels, showed that TRPV5 ablation increases number and size of osteoclasts but impairs osteoclast-mediated bone resorption. The latter is not in line with the observed decreased bone thickness in TRPV5 ${ }^{-1-}$ mice. Bisphosphonates also inhibit osteoclast-mediated bone resorption. The aim of this study was to evaluate the effect of alendronate on the expression of the $\mathrm{Ca}^{2+}$ transporters in bone, kidney, and duodenum and, importantly, the bone phenotype in TRPV5 ${ }^{-/}$mice. Wildtype (TRPV5 ${ }^{+/+}$) and TRPV5 ${ }^{-1-}$ mice were treated during $10 \mathrm{wk}$ with $2 \mathrm{mg} / \mathrm{kg}$ alendronate or vehicle weekly and housed in metabolic cages at the end of treatment. Urine and blood samples were taken for biochemical analysis, and duodenum, kidney, and femur were sampled. Expression of $\mathrm{Ca}^{2+}$ transporters and osteoclast ruffled border transporters in bone and cultured osteoclasts was determined by QPCR analysis. Femurs were scanned using $\mu \mathrm{CT}$, and resorption pit assays were performed in bone marrow cultures isolated from TRPV5 ${ }^{+/+}$and $\mathrm{TRPV5}^{-/-}$mice. Alendronate treatment enhanced bone thickness in TRPV5 ${ }^{+/+}$mice but also normalized the disturbed bone morphometry parameters in TRPV5 ${ }^{-1-}$ mice. Bone TRPV5 expression was specifically enhanced by alendronate, whereas the expression of $\mathrm{Ca}^{2+}$ transporters in kidney and intestine was not altered. The expression of the osteoclast ruffled border membrane proteins chloride channel 7 (CLC-7) and the vacuolar $\mathrm{H}^{+}$-ATPase did not differ between both genotypes, but alendronate significantly enhanced the expression and PTH levels in TRPV5 ${ }^{-1-}$ mice. The expression of TRPV5, CLC-7, and $\mathrm{H}^{+}-\mathrm{ATPase}$ in osteoclast cultures was not affected by alendronate. The number of resorption pits was reduced in TRPV5 ${ }^{-/-}$ bone marrow cultures, but the response to vitamin D was similar to that in TRPV5 ${ }^{+/+}$cultures. The alendronate-induced upregulation of TRPV5 in bone together with the decreased resorptive capacity of TRPV5 $^{-/-}$osteoclasts in vitro suggests that TRPV5 has an important role in osteoclast function. However, our data indicate that significant bone resorption still occurs in TRPV5 ${ }^{-1-}$ mice, because alendronate treatment normalized bone thickness in these mice. Thus, TRPV5 ${ }^{-1}$ mice are able to rescue the resulting defect in osteoclast-mediated bone resorption, possibly mediated by the long-term hypervitaminosis D or other (non)hormonal compensatory mechanisms.

J Bone Miner Res 2008;23:1815-1824. Published online on June 30, 2008; doi: 10.1359/JBMR.080613

Key words: TRPV5, osteoclast, alendronate, $1,25(\mathrm{OH})_{2} \mathrm{D}_{3}$, calcium

\section{INTRODUCTION}

$\mathrm{P}$ LASMA $\mathrm{CA}^{2+}$ CONCENTRATION is kept within narrow limits by tight regulation of intestinal $\mathrm{Ca}^{2+}$ absorption, renal $\mathrm{Ca}^{2+}$ reabsorption, and exchange of $\mathrm{Ca}^{2+}$ from bone. ${ }^{(1,2)}$ The active form of vitamin $\mathrm{D}, 1 \alpha, 25$-dihydroxyvitamin $\mathrm{D}_{3}$ $\left[1,25(\mathrm{OH})_{2} \mathrm{D}_{3}\right]$, and PTH are the main calcitropic hormones known to be involved in the maintenance of vertebrate $\mathrm{Ca}^{2+}$ homeostasis. ${ }^{(1)} 1,25(\mathrm{OH})_{2} \mathrm{D}_{3}-$ and PTHstimulated transcellular $\mathrm{Ca}^{2+}$ (re)absorption in kidney and intestine involves $\mathrm{Ca}^{2+}$ entry across the luminal membrane through the epithelial $\mathrm{Ca}^{2+}$ channels TRPV5 and TRPV6,

The authors state that they have no conflicts of interest. respectively. ${ }^{(2)}$ The majority of the body $\mathrm{Ca}^{2+}$ content is, thereafter, stored in bone, where the balanced processes of bone formation and resorption maintain bone homeostasis. ${ }^{(3)}$ The expression of TRPV5 and TRPV6 in bone was previously shown, but their physiological roles remained elusive. ${ }^{(4)}$ TRPV5 knockout (TRPV5 ${ }^{-/-}$) mice displayed a profound renal $\mathrm{Ca}^{2+}$ wasting and showed a bone phenotype characterized by reduced bone thickness. ${ }^{(5)}$ Interestingly, TRPV5 ablation was recently shown to result in increased numbers and size of osteoclasts, whereas osteoclast bone resorptive capacity in tibial bone marrow cultures from TRPV5 ${ }^{-1-}$ mice was severely decreased. ${ }^{(6)}$ These data suggested that TRPV5 is involved in osteoclast-mediated bone resorption. However, the impaired osteoclast activity seems

${ }^{1}$ Department of Physiology, Nijmegen Centre for Molecular Life Sciences, Radboud University, Nijmegen Medical Centre, Nijmegen, The Netherlands; ${ }^{2}$ Department of Internal Medicine, Erasmus Medical Centre, Rotterdam, The Netherlands; ${ }^{3}$ Department of Orthopedics, Erasmus Medical Centre, Rotterdam, The Netherlands. 
at variance with the observed bone phenotype in TRPV5 ${ }^{-1-}$ mice.

TRPV5 is a highly $\mathrm{Ca}^{2+}$-selective ion channel localized at the luminal membrane of the late distal convoluted tubule (DCT) and connecting tubule (CNT) in kidney, where transcellular $\mathrm{Ca}^{2+}$ reabsorption takes place. ${ }^{(1,2,7)}$ TRPV6 is the homologous epithelial $\mathrm{Ca}^{2+}$ channel localized along the brush-border membrane of duodenum. ${ }^{(1,2,8)}$ After $\mathrm{Ca}^{2+}$ entry across the luminal membrane in kidney or intestine, $\mathrm{Ca}^{2+}$ is bound to $\mathrm{Ca}^{2+}$-binding proteins (calbindins), and this complex either diffuses or, alternatively, is translocated by vesicular transport to the basolateral membrane. Thereafter, $\mathrm{Ca}^{2+}$ is extruded to the blood compartment by the $\mathrm{Na}^{+} / \mathrm{Ca}^{2+}$ exchanger (NCX1) and/or the plasma membrane $\mathrm{Ca}^{2+}$-ATPase (PMCA1b). ${ }^{(1,2,7)}$

It was recently shown that the phenotype of calbindin$\mathrm{D}_{28 \mathrm{~K}}$ and calbindin- $\mathrm{D}_{9 \mathrm{~K}}$ knockout mice is rather mild, particularly because of compensatory upregulation of the expression of other $\mathrm{Ca}^{2+}$-transporting proteins involved in $\mathrm{Ca}^{2+}$ (re)absorption, partly induced by hormonal counterregulation. ${ }^{(9-11)}$ In contrast, TRPV5 ${ }^{-/-}$mice showed a clear phenotype characterized by profound renal $\mathrm{Ca}^{2+}$ wasting caused by impaired active $\mathrm{Ca}^{2+}$ reabsorption in DCT and CNT, accompanied by reduced expression of the downstream $\mathrm{Ca}^{2+}$ transporters. ${ }^{(5,12)}$ To further study the significance of TRPV5, we showed that, when $\mathrm{Ca}^{2+}$ entry through TRPV5 in polarized monolayers of rabbit CNT/CCD is blocked with the potent inhibitor ruthenium red, this eliminated PTH-stimulated transepithelial $\mathrm{Ca}^{2+}$ transport and simultaneously decreased the expression of calbindin- $\mathrm{D}_{28 \mathrm{~K}}$ and the basolateral NCX1, whereas TRPV5 expression remained unaffected. ${ }^{(13)}$ Together, these data underline the importance of TRPV5 as the gatekeeper in renal active $\mathrm{Ca}^{2+}$ reabsorption and show that the $\mathrm{Ca}^{2+}$ influx through TRPV5 controls the expression of the downstream $\mathrm{Ca}^{2+}$ transport proteins. In addition, a significant hypervitaminosis D was present in TRPV5 ${ }^{-1-}$ mice, along with increased intestinal $\mathrm{Ca}^{2+}$ absorption. Furthermore, the hypervitaminosis $\mathrm{D}$ is responsible for the intestinal hyperabsorption of $\mathrm{Ca}^{2+}$ through upregulation of the intestinal $\mathrm{Ca}^{2+}$ transport proteins TRPV6 and calbindin- $\mathrm{D}_{9 \mathrm{~K}} \cdot{ }^{(14)}$

Previously, we showed that, in bone, TRPV5 localizes exclusively to the ruffled border of osteoclasts. ${ }^{(6)}$ Furthermore, calbindin- $\mathrm{D}_{9 \mathrm{~K}}$, calbindin- $\mathrm{D}_{28 \mathrm{~K}}, \mathrm{NCX} 1$, and PMCA1b were shown to be present in these bone cells. ${ }^{(6)}$ Together with the near absence of resorption pit formation by $\mathrm{TRPV5}^{-1-}$ osteoclasts, these data suggested that the transcellular $\mathrm{Ca}^{2+}$ transport machinery, and TRPV5 in particular, is essential for proper osteoclastic bone resorption. ${ }^{(6)}$

The balance of bone formation and resorption can be clinically influenced by the administration of bisphosphonates, which are used in the treatment of malignancyrelated hypercalcemia and osteolytic bone disease, primary and secondary hyperparathyroidism, Paget's disease of bone, and osteoporosis. ${ }^{(15,16)}$ Because bisphosphonates are potent inhibitors of osteoclast-mediated bone resorption, the action of these compounds in wildtype (TRPV $5^{+/+}$) and TRPV $5^{-/}$mice, as well as the effects on the expression of TRPV5 and TRPV6, may add to our knowledge of the physiological role(s) of these epithelial $\mathrm{Ca}^{2+}$ channels in bone homeostasis. ${ }^{(16)}$ Furthermore, the effect of bisphosphonate treatment on renal and duodenal $\mathrm{Ca}^{2+}$ (re)absorption has not been evaluated in detail.

The aim of this study was, therefore, to determine the in vivo effect of the bisphosphonate alendronate on $\mathrm{Ca}^{2+}$ and bone homeostasis. The expression of the $\mathrm{Ca}^{2+}$ transport proteins in bone, kidney, and intestine was determined by real-time QPCR analysis and/or semiquantitative immunohistochemistry. The action of alendronate on bone morphology in TRPV5 ${ }^{+/+}$mice and, importantly, the bone phenotype in TRPV5 ${ }^{-1-}$ mice, was evaluated by $\mu \mathrm{CT}$.

\section{MATERIALS AND METHODS}

\section{Alendronate treatment in TRPV $5^{+/+}$(wildtype) and TRPV5 ${ }^{-/-}$mice}

$\mathrm{TRPV}^{-/-}$mice were generated by targeted ablation of the TRPV5 gene. ${ }^{(5)}$ TRPV5 $^{+/+}$mice and TRPV5 ${ }^{-/-}$littermates were housed in a light- and temperature-controlled room with ad libitum access to deionized drinking water and standard pelleted chow $(0.25 \%$ [wt/vol] Na; $1.1 \%$ [wt/ vol] Ca). Eight-week-old TRPV5 ${ }^{+/+}$and TRPV5 ${ }^{-1-}$ mice were treated for $10 \mathrm{wk}$ with $2 \mathrm{mg} / \mathrm{kg}$ alendronate (3-amino1-hydroxypropylidene-1,1-bisphosphonate; $n=9$ ) or vehicle $(n=9)$ once weekly by subcutaneous injection. At the end of the treatment period, the animals were housed in metabolic cages enabling ration feeding and collection of 24-h urine samples under mineral oil, preventing evaporation. After termination of the metabolic experiments, blood samples were taken, and the animals were anesthetized and killed by cervical dislocation. Immediately thereafter, duodenum, kidney, and femur were sampled. Kidney cortex was immediately frozen in liquid nitrogen and, in addition, renal tissue was fixated for immunohistochemistry by immersion in $1 \%$ (wt/vol) periodate-lysine-paraformaldehyde (PLP) for $2 \mathrm{~h}$ and $15 \%$ (wt/vol) sucrose in PBS overnight. Subsequently, kidney and duodenum samples were stored at $-80^{\circ} \mathrm{C}$ until further processing. The animal ethics board of the Radboud University Nijmegen approved all animal studies.

\section{Analytical procedures}

Serum and urine $\mathrm{Ca}^{2+}$ concentrations were determined using a colorimetric assay as described previously. ${ }^{(17)}$ $\mathrm{Na}^{+}$and $\mathrm{Li}^{+}$concentrations were determined flamespectrophotometrically (Eppendorf FCM 6343), ${ }^{(12)}$ and urine $\mathrm{pH}$ was measured using an electronic ion analyzer (Hanna Instruments, Szeged, Hungary). In addition, deoxypyridinoline (DPD) was analyzed in urine (Biometra, San Francisco, CA, USA). Serum $1,25(\mathrm{OH})_{2} \mathrm{D}_{3}$ levels were determined with an $\left[{ }^{125} \mathrm{I}\right] 1,25(\mathrm{OH})_{2} \mathrm{D}_{3}$ radioimmunoassay (IDS, Fountain Hills, AZ, USA) and serum PTH using an immunoradiometric assay (Immutopics, San Clemente, CA, USA).

\section{Real-time QPCR analysis}

Total RNA was extracted from bone, kidney, and duodenum using TriZol Total RNA Isolation Reagent (Gibco BRL, Breda, The Netherlands). Femurs, from which the 
bone marrow was removed by flushing with PBS, were first homogenized using a Mikro Dismembrator S (Sartorius, Goettingen, Germany). The obtained RNA was subjected to DNase treatment and reverse transcribed. ${ }^{(4)}$ Subsequently, the cDNA was used to measure TRPV5 and TRPV6 mRNA in bone by real-time QPCR as described previously. ${ }^{(18)}$ In addition, the mRNA levels of the vacuolar $\mathrm{H}^{+}$-ATPase and the $\mathrm{Cl}^{-}$channel $\mathrm{ClC}-7$, which are present in the ruffled border membrane of osteoclasts and involved in bone resorption, were determined. ${ }^{(19-22)}$ Vacuolar $\mathrm{H}^{+}$-ATPase primer sequences were 5'-TCAGATCCTAAGCCGAAGTTGAG-3' and 5'-GACCAAGGCCACCTCTTCAC-3', and 5'-TCCACCTGGGATCATGGGCTCTATGT-3' for the probe. In the case of $\mathrm{ClC}-7$, these were 5'-CCTGTGGTGGAGGATGTAGGA-3', 5' TCTCCACAAACACCTTATGCTTCA-3', and 5' TCCAAGGCTTGATCCTGCGTTCCC-3', respectively. Furthermore, TRPV5 and calbindin- $\mathrm{D}_{28 \mathrm{~K}}$ mRNA expression in kidney and TRPV6 and calbindin- $\mathrm{D}_{9 \mathrm{~K}}$ mRNA levels in duodenum were determined. ${ }^{(14,23)}$ The mRNA expression level of the housekeeping gene hypoxanthine-guanine phosphoribosyl transferase (HPRT) was used as an endogenous control, which enabled calculation of specific mRNA expression levels as a ratio of HPRT.

\section{Immunohistochemistry}

Staining of kidney sections for TRPV5 and calbindin$\mathrm{D}_{28 \mathrm{~K}}$ was performed on cryosections of PLP-fixed kidney samples as described previously. ${ }^{(7,17)}$ For semiquantitative determination of protein abundance, images were made using a Zeiss fluorescence microscope equipped with a digital camera (Nikon DXM1200). Images were analyzed with the Image Pro Plus 4.1 image analysis software (Media Cybernetics, Silver Spring, MD, USA), resulting in quantification of the protein levels as the mean of integrated optical density (IOD).

\section{Bone analysis}

To evaluate the effect of alendronate on the bone phenotype in TRPV5 ${ }^{-1-}$ mice and the possible correlation between TRPV5 and TRPV6 expression and bone homeostasis, femurs from control and alendronate-treated TRPV $5^{+/+}$ and TRPV5 ${ }^{-1-}$ mice were scanned using the SkyScan 1072 microtomograph (SkyScan, Antwerp, Belgium). Scans were processed and a $3 \mathrm{D}$ morphometric analysis of the bone was performed using the 3D-Calculator project free software (http://www.eur.nl/fgg/orthopaedics) followed by additional analyses, using software available on http://www. skyscan.be/next/downloads.html. Measured parameters were expressed according to bone histomorphometry nomenclature. ${ }^{(24)}$

\section{Murine bone marrow cultures and resorption pit assay}

Murine bone marrow cultures were performed as described previously. ${ }^{(6)}$ In short, different $1,25(\mathrm{OH})_{2} \mathrm{D}_{3}$ concentrations were applied to bone marrow cultures for 6 days to study the effect of $1,25(\mathrm{OH})_{2} \mathrm{D}_{3}$ on bone resorption by TRPV5 ${ }^{+/+}$and TRPV5 ${ }^{-/}$osteoclasts. Thereafter, murine osteoclasts cultured on bovine cortical bone slices were lysed in water for Coomassie brilliant blue staining of resorption pits. Bovine cortical bone slices were sonicated in $10 \%$ (vol/vol) ammonia (Merck) for $10 \mathrm{~min}$. After extensive washing, the cells were incubated in filtered potassium aluminum sulfate (Sigma) for $10 \mathrm{~min}$ and subsequently stained with filtered Coomassie brilliant blue (Phastgel Blue R; Amersham Pharmacia Biotech) for $5 \mathrm{~s}$. The resorption pits were analyzed with BIOQUANT software (Bioquant, Nashville, TN, USA). In addition, we determined the effect of alendronate on the expression of TRPV5, the chloride channel CLC-7, and the vacuolar $\mathrm{H}^{+}$-ATPase in cultured osteoclasts by real-time QPCR analysis as described above. To this end, alendronate was applied to the osteoclasts for $24 \mathrm{~h}$ at a concentration of $10^{-5} \mathrm{M}$, after which RNA was extracted.

\section{Statistical analysis}

Data are expressed as means \pm SE. Statistical comparisons were analyzed by one-way ANOVA and Fisher's multiple comparison; $p<0.05$ was considered statistically significant. All analyses were performed using the StatView Statistical Package software (Power PC version 4.51) on an Apple iMac computer.

\section{RESULTS}

\section{Metabolic studies in alendronate-treated TRPV5 $5^{+/+}$ and $\mathrm{TRPV}^{-/-}$mice}

$\mathrm{TRPV5}^{+/+}$and TRPV5 ${ }^{-/-}$mice were treated for $10 \mathrm{wk}$ with $2 \mathrm{mg} / \mathrm{kg}$ alendronate or vehicle by weekly subcutaneous injections. The obtained metabolic data are shown in Table 1. Genetic ablation of TRPV5 resulted in an $\sim 10$-fold increase in $\mathrm{Ca}^{2+}$ excretion compared with $\mathrm{TRPV}^{+/+}$mice, an enhanced urine volume, and slightly elevated serum $\mathrm{Ca}^{2+}$ levels. Alendronate treatment significantly decreased $\mathrm{Ca}^{2+}$ excretion in TRPV5 ${ }^{-1-}$ mice, but calciuresis remained unaltered in $\mathrm{TRPV}^{+/+}$mice. Likewise, alendronate reduced the increased diuresis in TRPV5 ${ }^{-1-}$ mice but not in TRPV5 $5^{+/+}$mice. Serum Ca ${ }^{2+}$ levels, $\mathrm{Na}^{+}$excretion, $\mathrm{Li}^{+}$ clearance, and urine $\mathrm{pH}$ were not affected by alendronate treatment. TRPV5 ${ }^{-1-}$ mice showed a significantly increased serum $1,25(\mathrm{OH})_{2} \mathrm{D}_{3}$ concentration. Alendronate treatment did not affect serum $1,25(\mathrm{OH})_{2} \mathrm{D}_{3}$ levels in TRPV $5^{+/+}$ mice. TRPV5 ablation significantly increased serum $1,25(\mathrm{OH})_{2} \mathrm{D}_{3}$ levels, whereas alendronate normalized serum $1,25(\mathrm{OH})_{2} \mathrm{D}_{3}$ in these TRPV5 ${ }^{-1-}$ mice. Serum PTH levels were not altered in TRPV5 ${ }^{-/-}$mice and alendronatetreated $\mathrm{TRPV}^{+/+}$mice. Interestingly, alendronate markedly increased serum PTH levels in TRPV5 ${ }^{-1-}$ mice compared with untreated TRPV5 ${ }^{-/-}$and $\mathrm{TRPV}^{+/+}$mice. Urine DPD levels were significantly reduced in $\mathrm{TRPV}^{-1-}$ mice compared with untreated controls.

\section{Bone analysis}

To evaluate the effect of alendronate on bone morphology in TRPV5 ${ }^{+/+}$and TRPV5 ${ }^{-/-}$mice, femurs were scanned using $\mu \mathrm{CT}$. Detailed 3D morphometric analysis showed 
Table 1. Serum and Urine Parameters During Alendronate Treatment in TRPV5 ${ }^{+/+}$And TRPV5 ${ }^{-/-}$Mice

\begin{tabular}{|c|c|c|c|c|}
\hline & \multicolumn{2}{|c|}{$T R P V 5^{+/+}$} & \multicolumn{2}{|c|}{ TRPV5 $5^{-/-}$} \\
\hline & Controls & Alendronate & Controls & Alendronate \\
\hline \multicolumn{5}{|l|}{ Serum } \\
\hline $\mathrm{Ca}^{2+}(\mathrm{mM})$ & $2.36 \pm 0.02$ & $2.39 \pm 0.03$ & $2.49 \pm 0.03^{*}$ & $2.54 \pm 0.03 *$ \\
\hline PTH $(\mathrm{pg} / \mathrm{ml})$ & $23 \pm 8$ & $14 \pm 5$ & $23 \pm 5$ & $122 \pm 23^{* \dagger}$ \\
\hline $1,25(\mathrm{OH})_{2} \mathrm{D}_{3}(\mathrm{pM})$ & $395 \pm 19$ & $489 \pm 76$ & $575 \pm 70^{*}$ & $364 \pm 42^{\dagger}$ \\
\hline \multicolumn{5}{|l|}{ Urine } \\
\hline $\mathrm{Ca}^{2+}$ excretion $(\mu \mathrm{mol} / 24 \mathrm{~h})$ & $9.3 \pm 1.3$ & $7.6 \pm 0.6$ & $102 \pm 2 *$ & $85 \pm 3^{* \dagger}$ \\
\hline Diuresis $(\mathrm{ml} / 24 \mathrm{~h})$ & $2.2 \pm 0.5$ & $2.0 \pm 0.3$ & $6.2 \pm 0.1^{*}$ & $4.6 \pm 0.3^{* \dagger}$ \\
\hline $\mathrm{Na}^{+}$excretion $(\mathrm{mmol} / 24 \mathrm{~h})$ & $0.1 \pm 0.1$ & $0.1 \pm 0.1$ & $0.1 \pm 0.1$ & $0.2 \pm 0.1$ \\
\hline $\mathrm{Li}^{+}$clearance $(\mu \mathrm{L} / \mathrm{min})$ & $15 \pm 2$ & $12 \pm 1$ & $17 \pm 2$ & $18 \pm 2$ \\
\hline $\mathrm{pH}$ & $7.2 \pm 0.2$ & $7.3 \pm 0.2$ & $6.3 \pm 0.3^{*}$ & $6.2 \pm 0.2^{*}$ \\
\hline $\mathrm{DPD}(\mathrm{nM})$ & $51 \pm 12$ & $29 \pm 5$ & $32 \pm 4$ & $15 \pm 2^{\dagger}$ \\
\hline
\end{tabular}

Controls, mice treated with vehicle only; alendronate, mice treated for $10 \mathrm{wk}$ with alendronate $(2 \mathrm{mg} / \mathrm{kg}$ weekly). Data are presented as means $\pm \mathrm{SE}$ $* p<0.05$ vs. $\mathrm{TRPV}^{+/+}$controls.

${ }^{\dagger} p<0.05$ vs. TRPV $5^{-/-}$controls.

that trabecular thickness (Tb.Th), cortical thickness (Ct.Th), cortical volume (Ct.V.), and cortical bone volume fraction (Ct.V/Dp.V) were decreased in TRPV5 ${ }^{-1-}$ mice (Table 2). Treatment with alendronate increased the trabecular bone volume fraction (BV/TV), Ct.Th, and Ct.V/ Dp.V in TRPV5 ${ }^{+/+}$mice, confirming the therapeutic efficacy of this bone resorption inhibitor. Interestingly, alendronate increased Tb.Th, BV/TV, Ct.Th, Ct.V, and Ct.V/Dp.V. in TRPV5 ${ }^{-1-}$ mice to levels that did not differ from untreated TRPV $5^{+/+}$mice, showing that alendronate was able to normalize the bone morphology parameters in these mice.

\section{$m R N A$ expression of TRPV5 and osteoclast markers in bone and cultured osteoclasts}

Bone TRPV5 mRNA levels in femur, as determined by real-time QPCR analysis, were significantly enhanced by alendronate in TRPV5 ${ }^{+/+}$mice (Fig. 1A). In contrast, bone TRPV6 mRNA levels were unaffected by alendronate treatment (Fig. 1B). TRPV5 gene ablation did not alter the TRPV6 mRNA levels in femur. To further evaluate the effect of alendronate on osteoclasts, bone mRNA expression levels of the vacuolar $\mathrm{H}^{+}$-ATPase and the chloride channel ClC-7 were determined, which both are expressed at the ruffled border of the osteoclast and are involved in the acidification of resorption pits as part of the process of bone resorption. ${ }^{(19,20)}$ The vacuolar $\mathrm{H}^{+}$-ATPase (Fig. 2A) and ClC-7 mRNA expression (Fig. 2B) was not altered by TRPV5 ablation. Furthermore, alendronate treatment did not alter the expression of these osteoclast markers in $\mathrm{TRPV5}^{+/+}$mice. In TRPV5 ${ }^{-/-}$mice, however, alendronate significantly enhanced the bone vacuolar $\mathrm{H}^{+}$-ATPase and ClC-7 mRNA expression levels. To ascertain whether the above-described transcriptional regulation was the result of a direct effect of alendronate on the osteoclast, we determined the expression of these transport proteins in cultured osteoclasts treated with alendronate. In contrast to the alendronate-induced TRPV5 upregulation in bone, TRPV5 mRNA expression in cultured osteoclasts was not altered by alendronate application (Fig. 3A). Likewise, the expres- sion of the chloride channel CLC-7 (Fig. 3B) and the vacuolar $\mathrm{H}^{+}$-ATPase (Fig. 3C) was unaltered by alendronate.

Renal and duodenal expression of $\mathrm{Ca}^{2+}$ transporters

Alendronate administration did not change renal TRPV5 mRNA (Fig. 4A) or protein expression (Figs. 5A and 5C) in $\mathrm{TRPV}^{+/+}$mice as determined by real-time QPCR and semiquantitative immunohistochemistry, respectively. TRPV5 $^{-/-}$mice showed significantly decreased renal calbindin- $\mathrm{D}_{28 \mathrm{~K}}$ mRNA (Fig. $4 \mathrm{~B}$ ) and protein expression in DCT and CNT (Figs. 5B and 5D). However, calbindin$\mathrm{D}_{28 \mathrm{~K}}$ mRNA (Fig. 4B) and protein abundance (Figs. 5B and $5 \mathrm{D}$ ) in both genotypes were not affected by alendronate. TRPV5 ablation resulted in a significantly enhanced intestinal mRNA expression of the $\mathrm{Ca}^{2+}$ transporters TRPV6 (Fig. 6A) and calbindin- $\mathrm{D}_{9 \mathrm{~K}}$ (Fig. 6B). In both TRPV5 $^{+/+}$and TRPV5 ${ }^{-/-}$mice, duodenal TRPV6 and calbindin- $\mathrm{D}_{9 \mathrm{~K}} \mathrm{mRNA}$ levels were not altered by alendronate treatment.

\section{Murine bone marrow cultures and resorption pit assay}

When bone marrow from TRPV5 ${ }^{+/+}$and TRPV5 $5^{-1-}$ mice was cultured in the presence of FCS only, the number of resorption pits in TRPV $5^{-1-}$ was lower compared with wildtype cultures (Fig. 7). The addition of $1,25(\mathrm{OH})_{2} \mathrm{D}_{3}$ to the culture medium moderately increased the number of resorption pits in both TRPV5 ${ }^{+/+}$and $\mathrm{TRPV}^{-/}$cultures. Further increments of the $1,25(\mathrm{OH})_{2} \mathrm{D}_{3}$ concentration ultimately reduced the number of resorption pits in cultures from both genotypes. Osteoclast numbers were increased by $1,25(\mathrm{OH})_{2} \mathrm{D}_{3}$ treatment in both $\mathrm{TRPV}^{+/+}$and TRPV5 $^{-1-}$ mice (data not shown).

\section{DISCUSSION}

This study showed that treatment with the bone resorption inhibitor alendronate normalizes the reduced bone thickness in TRPV5 ${ }^{-/}$mice. This clearly indicated that significant bone resorption still occurs in these mice. In accor- 
Table 2. Bone Morphometry Parameters During Alendronate Treatment in TRPV5 ${ }^{+/+}$And TRPV5 $^{-/-}$Mice $^{-1}$

\begin{tabular}{|c|c|c|c|c|}
\hline & \multicolumn{2}{|c|}{$T R P V 5^{+/+}$} & \multicolumn{2}{|c|}{ TRPV5 $5^{-/-}$} \\
\hline & Controls & Alendronate & Controls & Alendronate \\
\hline \multicolumn{5}{|l|}{ Femoral head } \\
\hline Tb.Th $(\mu \mathrm{m})$ & $86 \pm 2$ & $85 \pm 2$ & $79 \pm 2 *$ & $85 \pm 2^{\dagger}$ \\
\hline Tb.V. $\left(\mathrm{mm}^{3}\right)$ & $0.9 \pm 0.1$ & $0.9 \pm 0.1$ & $0.9 \pm 0.1$ & $1.0 \pm 0.1$ \\
\hline BV/TV (\%) & $22 \pm 1$ & $31 \pm 1^{*}$ & $21 \pm 2$ & $28 \pm 2 * \dagger$ \\
\hline \multicolumn{5}{|l|}{ Diaphysis } \\
\hline Ct.Th $(\mu \mathrm{m})$ & $281 \pm 3$ & $308 \pm 9 *$ & $223 \pm 5^{*}$ & $268 \pm 6^{\dagger}$ \\
\hline Ct.V $\left(\mathrm{mm}^{3}\right)$ & $4.1 \pm 0.2$ & $4.4 \pm 0.2$ & $3.4 \pm 0.2 *$ & $4.0 \pm 0.3^{\dagger}$ \\
\hline Ct.V/Dp.V (\%) & $56 \pm 1$ & $61 \pm 1 *$ & $47 \pm 1 *$ & $56 \pm 1^{\dagger}$ \\
\hline
\end{tabular}

Bone morphometry parameters were determined by $\mu \mathrm{CT}$. Controls, mice treated with vehicle only; alendronate, mice treated for 10 wk with alendronate ( $2 \mathrm{mg} / \mathrm{kg}$ weekly). In the femoral head, trabecular thickness (Tb.Th), trabecular volume (Tb.V), bone volume (BV), total bone marrow volume including trabeculae (TV), and trabecular bone volume fraction (BV/TV) were determined. In the diaphysis, calculations were performed with regard to cortical thickness (Ct.Th), cortical volume (Ct.V), total diaphyseal volume (Dp.V), and cortical bone volume fraction (Ct.V/Dp.V). Data are presented as means $\pm \mathrm{SE}$.

$* p<0.05$ vs. TRPV5 ${ }^{+/+}$controls.

${ }^{\dagger} p<0.05$ vs. TRPV $^{-1-}$ controls.
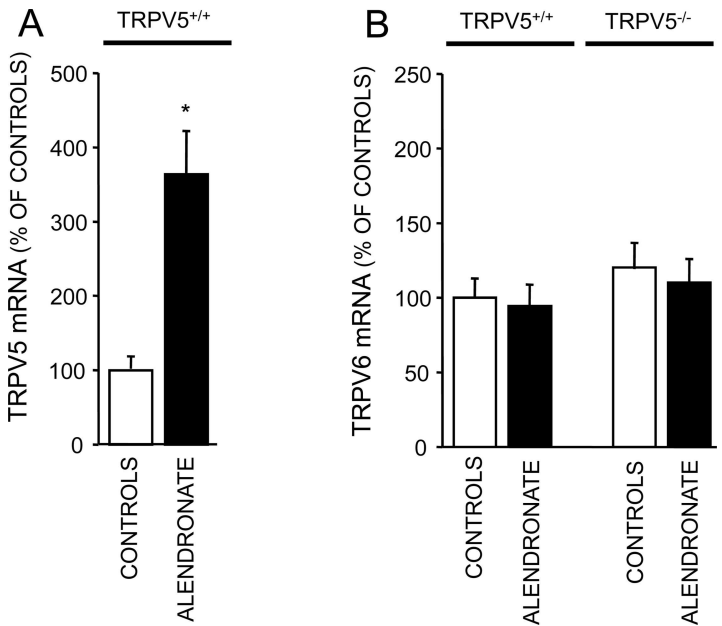

FIG. 1. mRNA expression of epithelial $\mathrm{Ca}^{2+}$ channels in bone during treatment with alendronate in TRPV $5^{+/+}$and $\mathrm{TRPV}^{-/-}$ mice. The effect of alendronate treatment on mRNA expression of the epithelial $\mathrm{Ca}^{2+}$ channels TRPV5 (A) and TRPV6 (B) in bone was determined by real-time OPCR analysis, expressed as the ratio of hypoxanthine-guanine phosphoribosyl transferase (HPRT) and depicted as percentage of TRPV5 ${ }^{+/+}$controls. Controls, mice treated with vehicle only; alendronate, mice treated for 10 wk with alendronate $(2 \mathrm{mg} / \mathrm{kg}$ weekly). Data are presented as means \pm SE. ${ }^{*} p<0.05$ vs. TRPV $5^{+/+}$controls. $N=9$ animals per group.

dance, the expression of other ruffled border transporters involved in osteoclast-mediated bone resorption (i.e., the vacuolar $\mathrm{H}^{+}$-ATPase and $\left.\mathrm{ClC}-7\right)$ remained unchanged in $\mathrm{TRPV}^{-/-}$mice. Interestingly, alendronate enhanced osteoclast TRPV5 expression, whereas the expression of the $\mathrm{Ca}^{2+}$ transporters in kidney and intestine was not affected. This indicated that alendronate specifically affects bone, without altering renal or intestinal active $\mathrm{Ca}^{2+}$ (re)absorption. Taken together, these data suggest that the severely impaired bone resorptive capacity that was shown in tibial bone marrow cultures from TRPV5 ${ }^{-/-}$mice $^{(6)}$ is rescued in vivo. Because osteoclast numbers are increased in
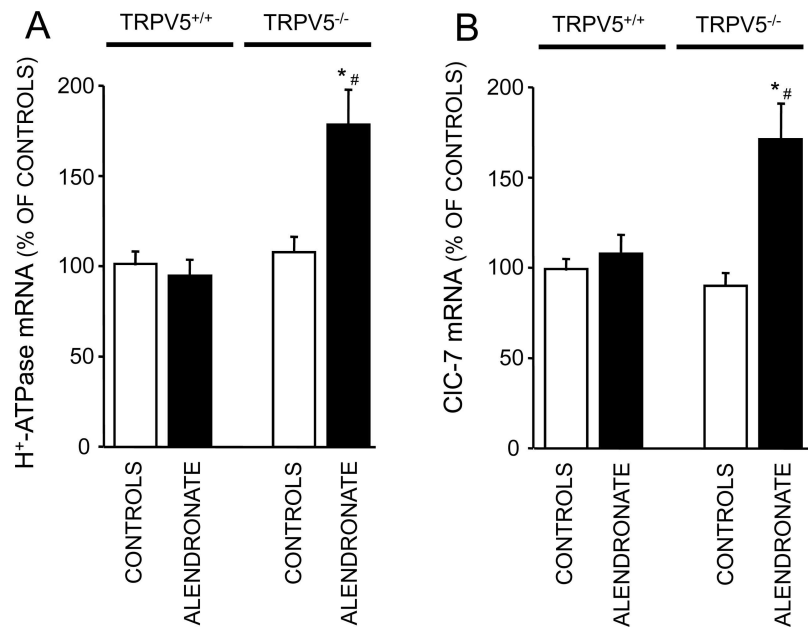

FIG. 2. mRNA expression of the vacuolar $\mathrm{H}^{+}$-ATPase and the $\mathrm{Cl}^{-}$channel ClC-7 in bone during treatment with alendronate in $\mathrm{TRPV5}^{+/+}$and TRPV5 ${ }^{-/-}$mice. The effect of alendronate treatment on mRNA expression of $\mathrm{H}^{+}$-ATPase (A) and ClC-7 (B) in bone was determined by real-time OPCR analysis, expressed as the ratio of hypoxanthine-guanine phosphoribosyl transferase (HPRT) and depicted as percentage of TRPV $5^{+/+}$controls. Controls, mice treated with vehicle only; alendronate, mice treated for 10 wk with alendronate $(2 \mathrm{mg} / \mathrm{kg}$ weekly). Data are presented as means \pm SE. ${ }^{*} p<0.05$ vs. TRPV5 ${ }^{+/+}$controls. ${ }^{\#} p<0.05$ vs. TRPV $^{-/-}$controls. $N=9$ animals per group.

TRPV5 $^{-1-}$ mice and these osteoclasts retain $1,25(\mathrm{OH})_{2} \mathrm{D}_{3}$ responsiveness, the rescue mechanism might involve hypervitaminosis $\mathrm{D}$.

Alendronate treatment during 10 wk enhanced bone thickness in TRPV $5^{+/+}$mice, which substantiates the therapeutic efficacy of this compound in mice. In TRPV5 ${ }^{-1-}$ mice, alendronate normalized the significantly diminished bone thickness and volume parameters compared with $\mathrm{TRPV}^{+/+}$mice and reduced urinary excretion of the bone resorption marker DPD. Furthermore, renal $\mathrm{Ca}^{2+}$ excretion was diminished by alendronate in these mice, which is in line with less $\mathrm{Ca}^{2+}$ being released from bone because of 


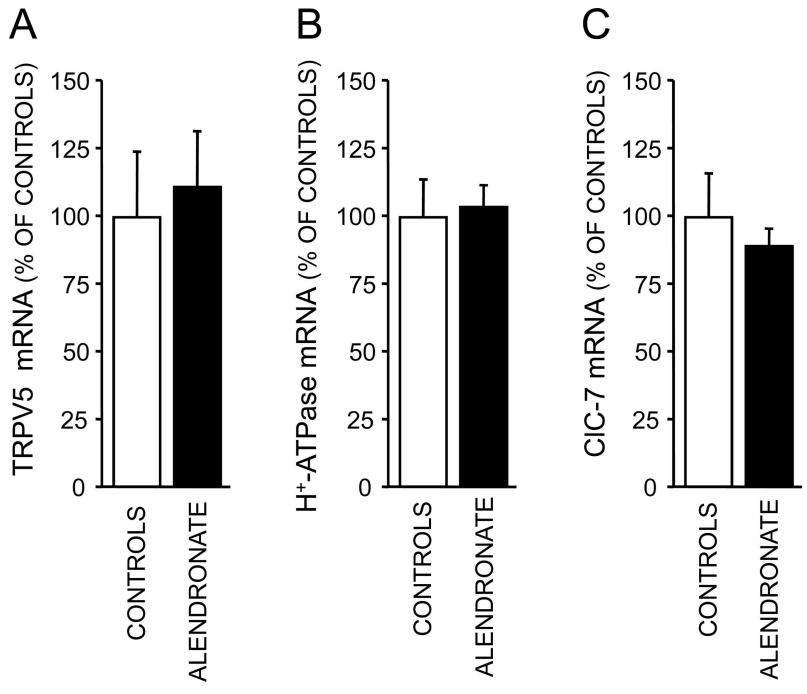

FIG. 3. mRNA expression of the epithelial $\mathrm{Ca}^{2+}$ channel TRPV5, the vacuolar $\mathrm{H}^{+}$-ATPase, and the $\mathrm{Cl}^{-}$channel $\mathrm{ClC}-7$ in cultured osteoclasts during treatment with alendronate. The effect of alendronate application during $24 \mathrm{~h}$ on mRNA expression of TRPV5 (A), $\mathrm{H}^{+}$-ATPase (B), and ClC-7 (C) in osteoclast cultures was determined by real-time QPCR analysis, expressed as the ratio of hypoxanthine-guanine phosphoribosyl transferase (HPRT) and depicted as percentage of untreated control osteoclast cultures. Controls, osteoclasts treated with vehicle only; alendronate, osteoclasts treated with $10^{-5} \mathrm{M}$ alendronate. Data are presented as means \pm SE. $N=5$ osteoclast cultures per condition.
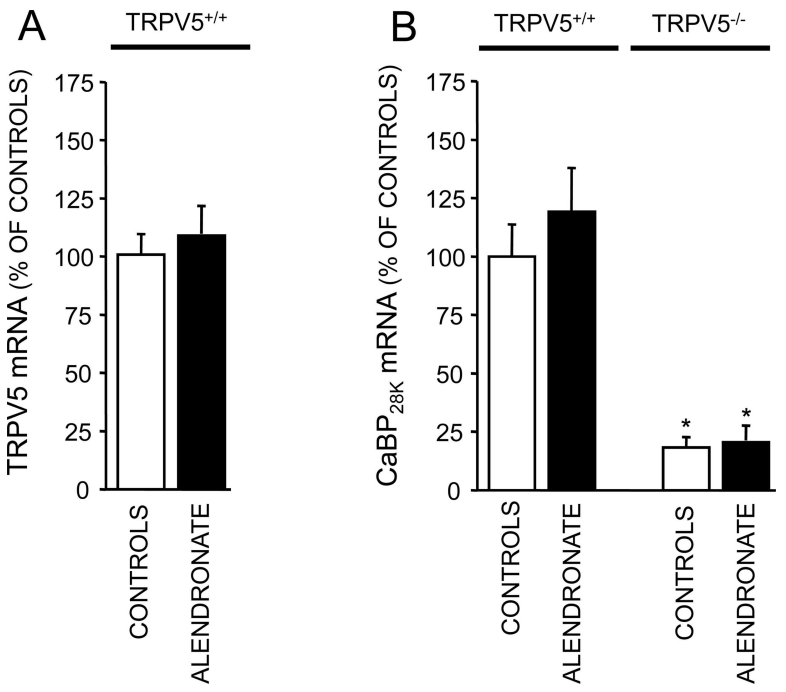

FIG. 4. mRNA expression of renal $\mathrm{Ca}^{2+}$ transporters during treatment with alendronate in TRPV $5^{+/+}$and $\mathrm{TRPV}^{-/-}$mice. The effect of alendronate treatment on renal mRNA expression of the epithelial $\mathrm{Ca}^{2+}$ channel TRPV5 (A) and the cytosolic $\mathrm{Ca}^{2+}$ binding protein calbindin- $\mathrm{D}_{28 \mathrm{~K}}\left(\mathrm{CaBP}_{28 \mathrm{~K}} ; \mathrm{B}\right)$ was determined by real-time QPCR analysis, expressed as the ratio of hypoxanthineguanine phosphoribosyl transferase (HPRT) and depicted as percentage of $\mathrm{TRPV}^{+/+}$controls. Controls, mice treated with vehicle only; alendronate, mice treated for $10 \mathrm{wk}$ with alendronate (2 $\mathrm{mg} / \mathrm{kg}$ weekly). Data are presented as means \pm SE. $* p<0.05$ vs. TRPV $^{+/+}$controls. $N=9$ animals per group. inhibition of bone resorption. Previous studies showed that, in bone, TRPV5 is exclusively expressed in the osteoclast ruffled border and that osteoclasts from TRPV $5^{-1-}$ mice are severely impaired in their bone resorptive capacity. ${ }^{(6)}$ This was exemplified by the near-absence of resorption pit formation by osteoclasts derived from bone marrow cultures of these knockout mice. ${ }^{(6)}$ These data suggested that TRPV5 is essential for proper osteoclastic bone resorption. The significant bone-sparing response to alendronate, however, indicated that TRPV $5^{-1-}$ mice retain significant osteoclast-mediated bone resorptive capacity. This was substantiated by the unaltered expression of the vacuolar $\mathrm{H}^{+}$ATPase and the chloride channel $\mathrm{ClC}-7$ in bones from $\mathrm{TRPV5}^{-1-}$ mice, which are expressed along with TRPV5 at the ruffled border of the osteoclast and are crucial to osteoclastic bone resorption. ${ }^{(19,20)}$ Moreover, mutations in these proteins have been shown to result in osteopetrosis, characterized by increased BMD and decreased bone length. ${ }^{(19,21,22,25)}$ Osteoclasts from ClC-7-deficient mice failed to form resorption pits, whereas osteoclast numbers were increased, features that resemble osteoclast abnormalities in TRPV5 $5^{-1-}$ mice. ${ }^{(6,21,25-27)}$ Thus, the severe malfunction of TRPV5 ${ }^{-1-}$ osteoclasts would, theoretically, be expected to lead to the clinical syndrome of osteopetrosis instead of the observed reduced bone thickness in TRPV5 $^{-1-}$ mice. ${ }^{(6)}$ Altogether, these data suggest that in vivo compensatory mechanisms are involved which rescue the impaired resorptive capacity of TRPV5-lacking osteoclasts.

In addition to TRPV5, TRPV6 is also expressed by os- teoclasts, suggesting that TRPV6 could compensate for the absence of TRPV5 in TRPV5 ${ }^{-1-}$ mice. ${ }^{(4,6)}$ However, the expression of TRPV6 in bone was unaltered in TRPV5 ${ }^{-1-}$ mice and not affected by alendronate treatment. Importantly, TRPV5 ${ }^{-/}$mice showed significant hypervitaminosis $\mathrm{D}$, which was previously shown to counteract the renal $\mathrm{Ca}^{2+}$ leak by inducing intestinal hyperabsorption of $\mathrm{Ca}^{2+}$ mediated by increased duodenal expression of the homologous epithelial $\mathrm{Ca}^{2+}$ channel TRPV6 and calbindin- $\mathrm{D}_{9 \mathrm{~K}} \cdot{ }^{(5,14)}$ In TRPV5/25-hydroxyvitamin- $\mathrm{D}_{3}-1 \alpha$-hydroxylase double knockout mice (TRPV5 $5^{-/-} / 1 \alpha-\mathrm{OHase}^{-/-}$), in addition to TRPV5 ablation, $1,25(\mathrm{OH})_{2} \mathrm{D}_{3}$ biosynthesis is impaired. ${ }^{(14)}$ The compensatory $\mathrm{Ca}^{2+}$ hyperabsorption observed in TRPV5 $5^{-l-}$ mice was absent in $\mathrm{TRPV}^{-1-} / 1 \alpha-\mathrm{OHase}^{-/-}$ mice. ${ }^{(14)}$ Importantly, the latter mice showed a distinct bone phenotype including reduced bone length, along with severe hypocalcemia and hyperparathyroidism. Whereas physiological doses of $1,25(\mathrm{OH})_{2} \mathrm{D}_{3}$ inhibit PTH-induced bone resorption, $1,25(\mathrm{OH})_{2} \mathrm{D}_{3}$ has been suggested to stimulate bone resorption by enhancing osteoclast formation when present at supraphysiological levels. ${ }^{(28,29)}$ Indeed, both the number of mature osteoclasts and osteoclast precursors in bone marrow of TRPV5 ${ }^{-1-}$ mice were increased, indicating an accelerated osteoclast differentiation pathway in the presence of hypervitaminosis D in these mice. ${ }^{(6)}$ Taken together, these data suggest that the increased $1,25(\mathrm{OH})_{2} \mathrm{D}_{3}$ levels not only lead to $\mathrm{Ca}^{2+}$ hyperabsorption but might also rescue the impaired osteoclast function, concurrently resulting in the maintenance of normocalcemia. To address this hypothesis, TRPV5 $5^{+/+}$and TRPV5 $5^{-/-}$bone 

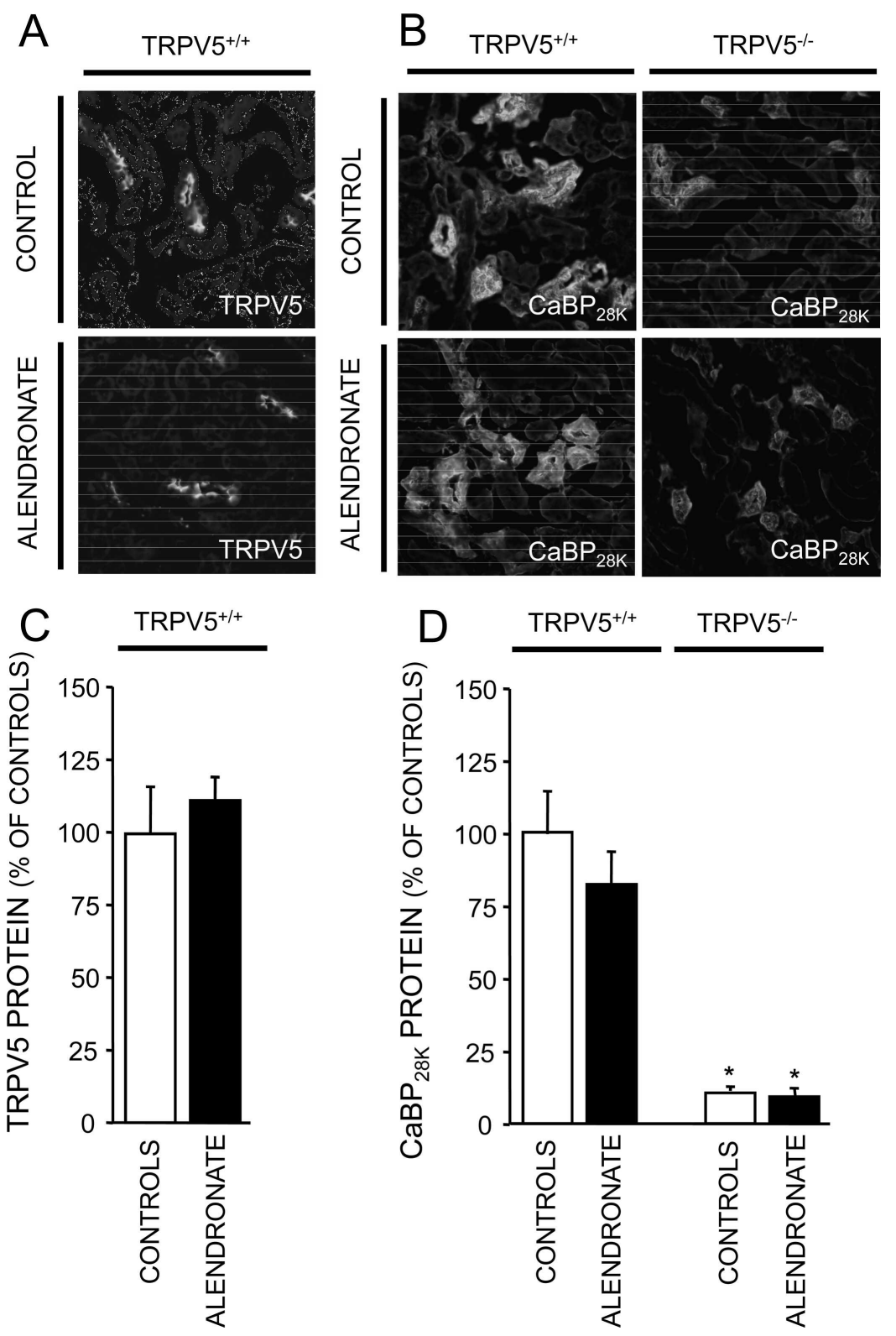

FIG. 5. Protein abundance of renal $\mathrm{Ca}^{2+}$ transporters during treatment with alendronate in TRPV5 ${ }^{+/}$and TRPV5 ${ }^{-/-}$mice. Representative immunohistochemical images of TRPV5 (A) and calbindin- $\mathrm{D}_{28 \mathrm{~K}}\left(\mathrm{CaBP}_{28 \mathrm{~K}}\right.$; B) staining in kidney cortex. Semiquantification of renal TRPV5 (C) and calbindin- $\mathrm{D}_{28 \mathrm{~K}}$ (D) protein abundance was performed by computerized analysis of immunohistochemical images. Data were calculated as integrated optical density (IOD; arbitrary units) and depicted as percentage of $\mathrm{TRPV}^{+/}$ controls. Controls, mice treated with vehicle only; alendronate, mice treated for $10 \mathrm{wk}$ with alendronate $(2 \mathrm{mg} / \mathrm{kg}$ weekly). Data are presented as means \pm SE. $* p<0.05$ vs. TRPV $^{+/+}$controls. $N=9$ animals per group.

marrow cultures were treated with different $1,25(\mathrm{OH})_{2} \mathrm{D}_{3}$ concentrations. These experiments substantiated that TRPV $5^{-/}$osteoclasts form less resorption pits, whereas their response to $1,25(\mathrm{OH})_{2} \mathrm{D}_{3}$ did not differ from $\mathrm{TRPV}^{+/+}$osteoclasts. The fact that $\mathrm{TRPV}^{-/}$osteoclasts retain the ability to enhance osteoclast numbers and resorption pit formation on stimulation by $1,25(\mathrm{OH})_{2} \mathrm{D}_{3}$ is in line with the aforementioned hypothesis. Applying increasing $1,25(\mathrm{OH})_{2} \mathrm{D}_{3}$ concentrations in 10 -fold increments eventually reduced the number of resorption pits and therefore bone resorption capacity in both TRPV $5^{+/+}$and TRPV5 $5^{-/-}$ bone marrow cultures. However, $1,25(\mathrm{OH})_{2} \mathrm{D}_{3}$ levels in TRPV5 $^{-1-}$ mice were significantly elevated but still remained within the same order of magnitude than in the wildtype animals, suggesting that this is not expected to lead to a decreased bone resorption. Thus, because osteoclasts stay responsive to $1,25(\mathrm{OH})_{2} \mathrm{D}_{3}$ and osteoclastogen- esis seems to be enhanced in these mice, the hypervitaminosis D could be involved in rescuing the osteoclast phenotype in vivo.

Interestingly, TRPV5 expression in bone was increased by alendronate treatment in TRPV $5^{+/+}$mice. However, the expression of TRPV6 and the osteoclast markers $\mathrm{ClC}-7$ and the vacuolar $\mathrm{H}^{+}$-ATPase was unchanged, nor was the expression of $\mathrm{Ca}^{2+}$ transporters in kidney and intestine altered. This indicated that osteoclast TRPV5 expression is specifically upregulated when bone resorption is inhibited by alendronate, substantiating that TRPV5 is important in osteoclast function. In contrast, alendronate did enhance ClC-7 and $\mathrm{H}^{+}$-ATPase expression in TRPV5 ${ }^{-1-}$ mice. Unlike other bisphosphonates, which affect osteoclastogenesis and induce apoptosis of mature osteoclasts, aminobisphosphonates such as alendronate are able to prevent bone resorption without diminishing osteoclast numbers 

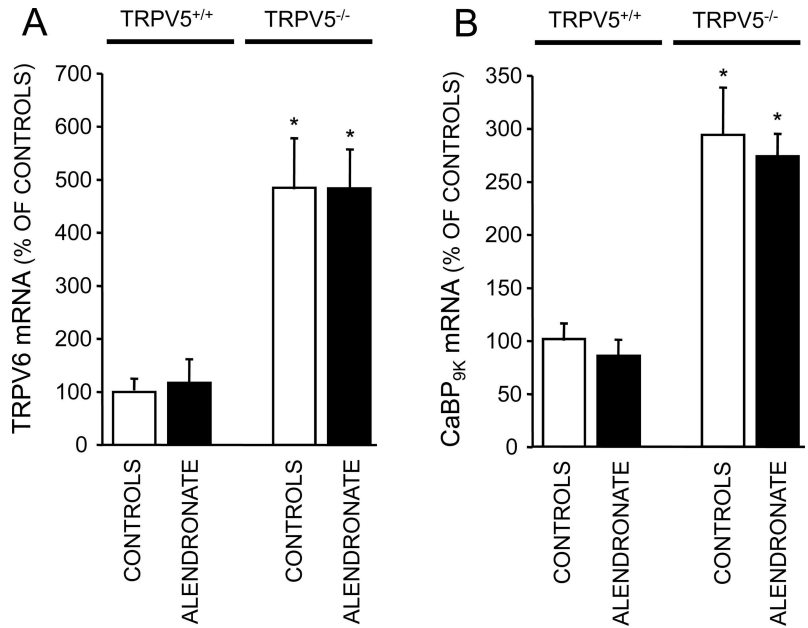

FIG. 6. mRNA expression of duodenal $\mathrm{Ca}^{2+}$ transporters during treatment with alendronate in TRPV $5^{+/+}$and $\mathrm{TRPV}^{-/-}$mice. The effect of alendronate treatment on duodenal mRNA expression of the epithelial $\mathrm{Ca}^{2+}$ channel TRPV6 (A) and the cytosolic $\mathrm{Ca}^{2+}$ binding protein calbindin- $\mathrm{D}_{9 \mathrm{~K}}\left(\mathrm{CaBP}_{9 \mathrm{~K}} ; \mathrm{B}\right)$ was determined by real-time QPCR analysis, expressed as the ratio of hypoxanthineguanine phosphoribosyl transferase (HPRT) and depicted as percentage of TRPV5 ${ }^{+/+}$controls. Controls, mice treated with vehicle only; alendronate, mice treated for $10 \mathrm{wk}$ with alendronate $(2$ $\mathrm{mg} / \mathrm{kg}$ weekly). Data are presented as means $\pm \mathrm{SE}$. ${ }^{*} p<0.05$ vs. TRPV $^{+/+}$controls. $N=9$ animals per group.

and have previously been shown to paradoxically increase their quantity. ${ }^{(16,30-35)}$ This effect was hypothesized to reflect a compensatory feedback mechanism caused by the reduced release of $\mathrm{Ca}^{2+}$ from bone. ${ }^{(16,36)}$ The upregulation of CLC-7 and $\mathrm{H}^{+}$-ATPase, transporters known to be involved in resorption pit acidification, observed in our study coincided with a significant rise in serum PTH levels in $\mathrm{TRPV5}^{-1-}$ mice. Because the stimulatory effect of PTH on osteoclast acidification as well as $\mathrm{H}^{+}$-ATPase and $\mathrm{ClC}-7$ has been previously shown, ${ }^{(16,34,37-41)}$ the increased PTH levels are likely responsible.

Whereas significantly increasing PTH levels, alendronate treatment decreased the elevated serum $1,25(\mathrm{OH})_{2} \mathrm{D}_{3}$ levels in TRPV5 ${ }^{-1-}$ mice. Although intriguing, these hormonal changes are not readily explained. In addition, because the hypervitaminosis D maintains the compensatory $\mathrm{Ca}^{2+}$ hyperabsorption in $\mathrm{TRPV}^{-/-}$mice, alendronate treatment would be expected to result in downregulation of the intestinal $\mathrm{Ca}^{2+}$ transporters. However, the duodenal expression of these transporters remained unchanged. Tentatively, the high serum PTH or any of its downstream effects is involved in maintaining the $\mathrm{Ca}^{2+}$ hyperabsorption. Whereas the stimulatory effect of PTH on $\mathrm{Ca}^{2+}$ transporter expression and $\mathrm{Ca}^{2+}$ reabsorption has been shown in kidney and PTH receptors are present in intestinal cells, the stimulatory effect on intestinal $\mathrm{Ca}^{2+}$ absorption is debated. ${ }^{(42-45)}$ These data indicate that the response to alendronate treatment is different and more exaggerated in $\mathrm{TRPV}^{-1-}$ mice compared with TRPV5 $5^{+/+}$mice. It is therefore likely that alendronate-mediated inhibition of bone resorption seriously challenges the fragile $\mathrm{Ca}^{2+}$ balance in these mice, necessitating at least the prolonged induction of PTH secre-

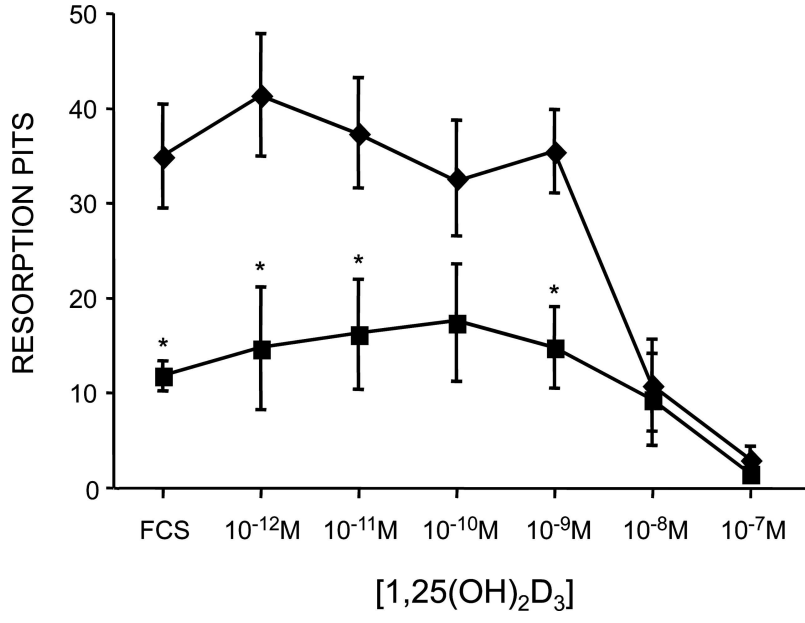

FIG. 7. Resorption pit assay in $\mathrm{TRPV}^{+/+}$and TRPV5 $5^{-/-}$bone marrow cultures. The effect of $1,25(\mathrm{OH})_{2} \mathrm{D}_{3}$ application on bone resorption was evaluated in bone marrow cultures derived from TRPV5 ${ }^{+/+}$and TRPV5 ${ }^{-/-}$mice. The number of resorption pits was determined by computerized analysis. FCS, fetal calf serum. $\bullet$, TRPV5 $^{+/+}$bone marrow cultures; $\mathbf{Q}$, TRPV5 ${ }^{-/-}$bone marrow cultures. Data are presented as means \pm SE. $* p<0.05$ vs. TRPV5 ${ }^{+/+}$ bone marrow cultures. $N=6$ bone marrow cultures per condition.

tion to ultimately maintain normocalcemia. However, the exact mechanism explaining the adapted hormone status in TRPV5 ${ }^{-/}$mice remains to be elucidated and warrants further study.

Taken together, our data suggest that the impaired bone resorption by TRPV5 ${ }^{-1-}$ osteoclasts determined in vitro is rescued to a substantial degree in $\mathrm{TRPV}^{-/-}$mice in vivo. Possibly, the hypervitaminosis $\mathrm{D}$, in addition to causing $\mathrm{Ca}^{2+}$ hyperabsorption in intestine, is also involved in the compensatory mechanism rescuing bone resorptive capacity. The apparent interruption of this rescue mechanism by alendronate treatment, whereas increasing bone thickness, seems to critically jeopardize $\mathrm{Ca}^{2+}$ homeostasis, leading to several compensatory effects including increased PTH secretion. However, these data do not yet explain the bone phenotype in TRPV5 ${ }^{-1-}$ mice. ${ }^{(5,14)}$ In the presence of an intrinsic defect of bone resorption, reduced bone formation is likely involved. Because bone formation and resorption were shown to be closely related processes, which show a considerable amount of cross-talk, an altered bone formation-resorption coupling might contribute to the reduced bone thickness. ${ }^{(46-49)}$ In addition, the primary renal $\mathrm{Ca}^{2+}$ wasting causes a negative $\mathrm{Ca}^{2+}$ balance, and therefore, less $\mathrm{Ca}^{2+}$ may be available for bone formation. ${ }^{(5)}$ Of note, $1,25(\mathrm{OH})_{2} \mathrm{D}_{3}$ treatment of murine osteoblasts was previously shown to inhibit the development of a mature osteoblast phenotype and matrix mineralization. ${ }^{(50)}$ Further studies are needed to unravel the exact relationship between TRPV5 ablation, osteoclast and osteoblast function, serum $1,25(\mathrm{OH})_{2} \mathrm{D}_{3}$ and PTH levels, and the reduced bone thickness in TRPV5 ${ }^{-1-}$ mice.

\section{ACKNOWLEDGMENTS}

This work was supported by grants from the Dutch Kidney Foundation (C10.1881 and C03.6017), EURYI 2006 
award, and the Netherlands Organization for Scientific Research (Zon-Mw 016.006.001 and 916.56.021). The authors thank the Central Animal Facility of the Radboud University Nijmegen for technical support in this study.

\section{REFERENCES}

1. Hoenderop JG, Nilius B, Bindels RJ 2005 Calcium absorption across epithelia. Physiol Rev 85:373-422.

2. Nijenhuis T, Hoenderop JG, Bindels RJ 2005 TRPV5 and TRPV6 in $\mathrm{Ca}^{2+}$ (re)absorption: Regulating $\mathrm{Ca}^{2+}$ entry at the gate. Pflugers Arch 451:181-192.

3. Harada S, Rodan GA 2003 Control of osteoblast function and regulation of bone mass. Nature 423:349-355.

4. Nijenhuis T, Hoenderop JG, van der Kemp AW, Bindels RJ 2003 Localization and regulation of the epithelial $\mathrm{Ca}^{2+}$ channel TRPV6 in the kidney. J Am Soc Nephrol 14:2731-2740.

5. Hoenderop JG, van Leeuwen JP, van der Eerden B, Kersten F, van der Kemp AW, Mérrliat A, Waarsing E, Rossier B, Vallon V, Hummler E, Bindels RJ 2003 Renal $\mathrm{Ca}^{2+}$ wasting, hyperabsorption and reduced bone thickness in mice lacking TRPV5. J Clin Invest 112:1906-1914.

6. van der Eerden BC, Hoenderop JG, de Vries TJ, Schoenmaker T, Buurman CJ, Uitterlinden AG, Pols HA, Bindels RJ, van Leeuwen JP 2005 The epithelial $\mathrm{Ca}^{2+}$ channel TRPV5 is essential for proper osteoclastic bone resorption. Proc Natl Acad Sci USA 102:17507-17512.

7. Hoenderop JG, van der Kemp AW, Hartog A, van de Graaf SF, van Os CH, Willems PH, Bindels RJ 1999 Molecular identification of the apical $\mathrm{Ca}^{2+}$ channel in 1, 25-dihydroxyvitamin $\mathrm{D}_{3}$-responsive epithelia. J Biol Chem 274:8375-8378.

8. Peng JB, Chen XZ, Berger UV, Vassilev PM, Tsukaguchi H, Brown EM, Hediger MA 1999 Molecular cloning and characterization of a channel-like transporter mediating intestinal calcium absorption. J Biol Chem 274:22739-22746.

9. Lee GS, Lee KY, Choi KC, Ryu YH, Paik SG, Oh GT, Jeung EB 2007 Phenotype of a calbindin-D9k gene knockout is compensated for by the induction of other calcium transporter genes in a mouse model. J Bone Miner Res 22:1968-1978.

10. Kutuzova GD, Akhter S, Christakos S, Vanhooke J, KimmelJehan C, Deluca HF 2006 Calbindin D(9k) knockout mice are indistinguishable from wild-type mice in phenotype and serum calcium level. Proc Natl Acad Sci USA 103:12377-12381.

11. Zheng W, Xie Y, Li G, Kong J, Feng JQ, Li YC 2004 Critical role of calbindin-D28k in calcium homeostasis revealed by mice lacking both vitamin $\mathrm{D}$ receptor and calbindin-D28k. J Biol Chem 279:52406-52413.

12. Nijenhuis T, Vallon V, van der Kemp AW, Loffing J, Hoenderop JG, Bindels RJ 2005 Enhanced passive $\mathrm{Ca}^{2+}$ reabsorption and reduced $\mathrm{Mg}^{2+}$ channel abundance explains thiazideinduced hypocalciuria and hypomagnesemia. J Clin Invest 115:1651-1658.

13. van Abel M, Hoenderop JG, Friedlaender MM, van Leeuwen JP, Bindels RJ 2005 Coordinated control of renal Ca ${ }^{2+}$ transport proteins by parathyroid hormone. Kidney Int 68:17081721.

14. Renkema KY, Nijenhuis T, Van der Eerden BCJ, Van der Kemp AWCM, Weinans H, van Leeuwen JP, Bindels RJM, Hoenderop JGJ 2005 Hypervitaminosis D mediates compensatory $\mathrm{Ca}^{2+}$ hyperabsorption in TRPV5 knockout mice. J Am Soc Nephrol 16:3188-3195.

15. Reszka AA, Rodan GA 2003 Mechanism of action of bisphosphonates. Curr Osteoporos Rep 1:45-52.

16. Rogers MJ, Gordon S, Benford HL, Coxon FP, Luckman SP, Monkkonen J, Frith JC 2000 Cellular and molecular mechanisms of action of bisphosphonates. Cancer 88(12 Suppl):29612978.

17. Hoenderop JG, Muller D, Van Der Kemp AW, Hartog A, Suzuki M, Ishibashi K, Imai M, Sweep F, Willems PH, Van Os $\mathrm{CH}$, Bindels RJ 2001 Calcitriol controls the epithelial calcium channel in kidney. J Am Soc Nephrol 12:1342-1349.
18. Nijenhuis T, Hoenderop JG, Loffing J, van der Kemp AW, Van Os C, Bindels RJ 2003 Thiazide-induced hypocalciuria is accompanied by a decreased expression of $\mathrm{Ca}^{2+}$ transporting proteins in the distal tubule. Kidney Int 64:555-564.

19. Frattini A, Orchard PJ, Sobacchi C, Giliani S, Abinun M, Mattsson JP, Keeling DJ, Andersson AK, Wallbrandt P, Zecca L, Notarangelo LD, Vezzoni P, Villa A 2000 Defects in TCIRG1 subunit of the vacuolar proton pump are responsible for a subset of human autosomal recessive osteopetrosis. Nat Genet 25:343-346.

20. Cleiren E, Benichou O, Van Hul E, Gram J, Bollerslev J, Singer FR, Beaverson K, Aledo A, Whyte MP, Yoneyama T, deVernejoul MC, Van Hul W 2001 Albers-Schonberg disease (autosomal dominant osteopetrosis, type II) results from mutations in the $\mathrm{ClCN} 7$ chloride channel gene. Hum Mol Genet 10:2861-2867.

21. Kornak U, Kasper D, Bosl MR, Kaiser E, Schweizer M, Schulz A, Friedrich W, Delling G, Jentsch TJ 2001 Loss of the ClC-7 chloride channel leads to osteopetrosis in mice and man. Cell 104:205-215.

22. Kornak U, Schulz A, Friedrich W, Uhlhaas S, Kremens B, Voit T, Hasan C, Bode U, Jentsch TJ, Kubisch C 2000 Mutations in the a3 subunit of the vacuolar $\mathrm{H}^{+}$-ATPase cause infantile malignant osteopetrosis. Hum Mol Genet 9:2059-2063.

23. van Abel M, Hoenderop JG, van der Kemp AW, van Leeuwen JP, Bindels RJ 2003 Regulation of the epithelial $\mathrm{Ca}^{2+}$ channels in small intestine as studied by quantitative mRNA detection. Am J Physiol Gastroinstest Liver Physiol 285:G78-G85.

24. Parfitt AM, Drezner MK, Glorieux FH, Kanis JA, Malluche H, Meunier PJ, Ott SM, Recker RR 1987 Bone histomorphometry: Standardization of nomenclature, symbols, and units. Report of the ASBMR Histomorphometry Nomenclature Committee. J Bone Miner Res 2:595-610.

25. Pettersson U, Albagha OM, Mirolo M, Taranta A, Frattini A, McGuigan FE, Vezzoni P, Teti A, Van Hul W, Reid DM, Villa A, Ralston SH 2005 Polymorphisms of the CLCN7 Gene Are Associated With BMD in Women. J Bone Miner Res 20:19601967.

26. Henriksen K, Gram J, Schaller S, Dahl BH, Dziegiel MH, Bollerslev J, Karsdal MA 2004 Characterization of osteoclasts from patients harboring a G215R mutation in ClC-7 causing autosomal dominant osteopetrosis type II. Am J Pathol 164:1537-1545.

27. Laitala-Leinonen T, Lowik C, Papapoulos S, Vaananen HK 1999 Inhibition of intravacuolar acidification by antisense RNA decreases osteoclast differentiation and bone resorption in vitro. J Cell Sci 112:3657-3666.

28. Suda T, Ueno Y, Fujii K, Shinki T 2003 Vitamin D and bone. J Cell Biochem 88:259-266.

29. Smith EA, Frankenburg EP, Goldstein SA, Koshizuka K, Elstner E, Said J, Kubota T, Uskokovic M, Koeffler HP 2000 Effects of long-term administration of vitamin $\mathrm{D}_{3}$ analogs to mice. J Endocrinol 165:163-172.

30. Marshall MJ, Wilson AS, Davie MW 1990 Effects of (3-amino1-hydroxypropylidene)-1,1-bisphosphonate on mouse osteoclasts. J Bone Miner Res 5:955-962.

31. Holt I, Marshall MJ, Davie MW 1994 Pamidronate stimulates recruitment and decreases longevity of osteoclast nuclei in mice. Semin Arthritis Rheum 23:263-264.

32. Marshall MJ, Holt I, Davie MW 1993 Osteoclast recruitment in mice is stimulated by (3-amino-1-hydroxypropylidene)-1,1bisphosphonate. Calcif Tissue Int 52:21-25.

33. van Beek ER, Lowik CW, Papapoulos SE 1997 Effect of alendronate treatment on the osteoclastogenic potential of bone marrow cells in mice. Bone 20:335-340.

34. Sato M, Grasser W 1990 Effects of bisphosphonates on isolated rat osteoclasts as examined by reflected light microscopy. J Bone Miner Res 5:31-40.

35. Breuil V, Cosman F, Stein L, Horbert W, Nieves J, Shen V, 
Lindsay R, Dempster DW 1998 Human osteoclast formation and activity in vitro: Effects of alendronate. J Bone Miner Res 13:1721-1729.

36. Endo Y, Nakamura M, Kikuchi T, Shinoda H, Takeda Y, Nitta Y, Kumagai K 1993 Aminoalkylbisphosphonates, potent inhibitors of bone resorption, induce a prolonged stimulation of histamine synthesis and increase macrophages, granulocytes, and osteoclasts in vivo. Calcif Tissue Int 52:248-254.

37. Blair HC, Athanasou NA 2004 Recent advances in osteoclast biology and pathological bone resorption. Histol Histopathol 19:189-199.

38. Gay CV, Weber JA 2000 Regulation of differentiated osteoclasts. Crit Rev Eukaryot Gene Expr 10:213-230.

39. Vaananen HK, Karhukorpi EK, Sundquist K, Wallmark B, Roininen I, Hentunen T, Tuukkanen J, Lakkakorpi P 1990 Evidence for the presence of a proton pump of the vacuolar $\mathrm{H}^{+}$-ATPase type in the ruffled borders of osteoclasts. J Cell Biol 111:1305-1311.

40. Gay CV, Kief NL, Bekker PJ 1993 Effect of estrogen on acidification in osteoclasts. Biochem Biophys Res Commun 192:1251-1259.

41. Sato M, Grasser W, Endo N, Akins R, Simmons H, Thompson DD, Golub E, Rodan GA 1991 Bisphosphonate action. Alendronate localization in rat bone and effects on osteoclast ultrastructure. J Clin Invest 88:2095-2105.

42. Watson PH, Fraher LJ, Hendy GN, Chung UI, Kisiel M, Natale BV, Hodsman AB 2000 Nuclear localization of the type 1 $\mathrm{PTH} / \mathrm{PTHrP}$ receptor in rat tissues. J Bone Miner Res 15:1033-1044.

43. Sterling TM, Nemere I 2007 Calcium uptake and membrane trafficking in response to PTH or 25(OH)D3 in polarized intestinal epithelial cells. Steroids 72:151-157.

44. Gentili C, Morelli S, de Boland AR 2003 Characterization of $\mathrm{PTH} / \mathrm{PTHrP}$ receptor in rat duodenum: Effects of ageing. $\mathrm{J}$ Cell Biochem 88:1157-1167.

45. Nemere I, Larsson D 2002 Does PTH have a direct effect on intestine? J Cell Biochem 86:29-34.

46. Karsdal MA, Henriksen K, Sorensen MG, Gram J, Schaller S,
Dziegiel MH, Heegaard AM, Christophersen P, Martin TJ, Christiansen C, Bollerslev J 2005 Acidification of the osteoclastic resorption compartment provides insight into the coupling of bone formation to bone resorption. Am J Pathol 166:467-476.

47. Udagawa N, Takahashi N, Jimi E, Matsuzaki K, Tsurukai T, Itoh K, Nakagawa N, Yasuda H, Goto M, Tsuda E, Higashio K, Gillespie MT, Martin TJ, Suda T 1999 Osteoblasts/stromal cells stimulate osteoclast activation through expression of osteoclast differentiation factor/RANKL but not macrophage colony-stimulating factor: Receptor activator of NF-kappa B ligand. Bone 25:517-523.

48. Martin TJ, Sims NA 2005 Osteoclast-derived activity in the coupling of bone formation to resorption. Trends Mol Med 11:76-81.

49. Martin TJ, Ng KW 1994 Mechanisms by which cells of the osteoblast lineage control osteoclast formation and activity. J Cell Biochem 56:357-366.

50. Fratzl-Zelman N, Glantschnig H, Rumpler M, Nader A, Ellinger A, Varga F 2003 The expression of matrix metalloproteinase-13 and osteocalcin in mouse osteoblasts is related to osteoblastic differentiation and is modulated by 1,25 dihydroxyvitamin- $\mathrm{D}_{3}$ and thyroid hormones. Cell Biol Int 27:459-468.

Address reprint requests to: René JM Bindels, PhD 286 Physiology/NCMLS Department of Physiology Radboud University Nijmegen Medical Centre PO Box 9101

6500 HB Nijmegen, The Netherlands E-mail:R.Bindels@ncmls.ru.nl

Received in original form November 20, 2007; revised form April 21, 2008; accepted June 27, 2008. 